\title{
La figura del Cristo Médico y la acción terapeútica del gnóstico en Evagrio Póntico
}

\author{
SANTIAGO HERNÁN VÁZQUEZ* \\ CONICET-Universidad Nacional de Cuyo (Argentina) \\ santiagohernanvazquez@gmail.com
}

\begin{abstract}
Resumen
La figura del $A b b a$, central en el monacato cristiano primitivo, recibe en el pensamiento de Evagrio Póntico, primer sistematizador de la espiritualidad monástica, la significativa denominación de "Gnóstico" pues se trata del monje que ha alcanzado un cierto grado de ciencia espiritual -natural primero, sobrenatural después- luego de haber atravesado la Praktikée. Esta última constituye, en la comprensión evagriana del itinerario cristiano, la primera etapa del progreso espiritual caracterizada principalmente por el cumplimiento de los mandamientos con el fin de obtener la virtud. Al cabo de la Praktikée, se alcanza la apátheia (establecimiento de un estado katà phýsin de la parte pasional, que no supresión de ésta) que constituye una condición propicia del alma para recibir la ciencia presente en las cosas y en los seres racionales. Evagrio llama "gnóstico" a quien ha recibido por lo menos las primicias de esta ciencia o gnosis. Sitúa así aquel "ministerio de la palabra" que el monacato asigna al $A b b a$, en el marco de su esquema de la vida cristiana, atribuyéndole una función medicinal que encuentra en la figura -cara al cristianismo tardoantiguo- del Cristo médico su arquetipo, su especificidad y su raíz. Nos interesa examinar en esta ocasión el modo en que aparece esta figura del Cristo en la obra de Evagrio Póntico y cómo ella constituiría el modelo y la raíz del ministerio terapeútico que, en el pensamiento evagriano, puede ejercer el gnóstico.
\end{abstract}

Palabras clave: Cristo médico, gnóstico, palabra, conocimiento, enfermedad.

\section{The figure of the Christ Physician and the therapeutic action of the Gnostic in Evagrius Ponticus}

\begin{abstract}
The Abba figure, central to early Christian monasticism, receives in the thought of Evagrius Ponticus (the first systematizer of monastic spirituality) the significant denomination of "Gnostic" because it is the monk who has attained a certain degree of spiritual science after having crossed the Praktike. The latter constitutes, in the evagriana understanding of the Christian itinerary, the first stage of the spiritual progress characterized mainly by the fulfillment of the commandments in order to obtain the virtue. At the end of the Praktiké, the apatheia (establishment of a state katà physin of the passionate part) is reached, which constitutes a propitious condition of the soul to receive the science present in things and rational beings. Evagrius calls "gnostic" who has received at least the first fruits of this science or gnosis. The "ministry of the word" that monasticism assigns to the Abba, is, for Evagrius, within this framework of Christian life. Our Author attributes the gnostic a medicinal function which finds in the figure - very important for the Late Antique Christianity- of the "Christ Physician", its archetype, its specificity and its root. We are interested in examining on this occasion how this figure of Christ appears in the work of Evagrius Ponticus and how it would constitute the model and root of the therapeutic ministry that, in Evagrian thought, can be exercised by the Gnostic.
\end{abstract}

Keywords: Christ Physician, gnostic, word, knowledge, disease.

* Licenciado en Psicología. Profesor en Psicología. Académico del Centro de estudios filosóficos medievales. Instituto de Filosofía, Facultad de Filosofía y Letras. Universidad Nacional de Cuyo.

Recibido: 21/Julio/2017 - Aceptado: 19/Octubre/2017 


\section{INTRODUCCIÓN}

Sin duda, una figura característica y distintiva del monacato cristiano primitivo es la del Abba o anciano. Éste es, en sentido lato, un monje experimentado que puede, en virtud de su progreso espiritual, ejercer un auténtico ministerio de la palabra que auxilia a los hombres hostigados por sus pensamientos y pasiones, y por tentaciones demoníacas. Evagrio Póntico, personaje eminente del monacato egipcio del Siglo IV, desarrolló una amplia obra filosófica, teológica y espiritual en la que se pueden encontrar claramente perfilados los fundamentos de esta auténtica institución monástica del $A b b a$ en tanto administrador de la palabra. Nos interesa detenernos aquí en uno de los principales fundamentos de dicha institución y que es el que tiene que ver con la figura del Cristo médico.

El $A b b a$ recibe en el pensamiento evagriano la significativa denominación de Gnóstico pues se trata del monje que ha alcanzado un cierto grado de ciencia espiritual - natural primero, sobrenatural después- luego de haber atravesado la Praktiké. Esta última constituye, en la comprensión evagriana del itinerario cristiano, la primera etapa del progreso espiritual caracterizada principalmente por el cumplimiento de los mandamientos con el fin de obtener la virtud u orientación katà phýsin (acorde a la naturaleza) de la parte pasional del alma. Al cabo de la Praktiké, se alcanza la apátheia (establecimiento de un estado katà phýsin de la parte pasional, que no supresión de ésta) que constituye una condición propicia del alma para recibir la ciencia presente en las cosas y en los seres racionales ${ }^{1}$. Evagrio llama "Gnóstico" a quien ha recibido por lo menos las primicias de esta ciencia o gnosis. Sitúa así aquel "ministerio de la palabra" que el monacato asigna al $A b b a$, en el marco de su esquema de la vida cristiana, atribuyéndole una función medicinal que encuentra en la figura -cara al cristianismo tardoantiguo- del Cristo médico su arquetipo, su especificidad y su raíz.

En este marco el objetivo que persigue nuestro estudio es doble: por un lado, indagar en el modo en que el tópico del Cristo médico se presenta en Evagrio. Por otro, visualizar el modo en que la figura del Cristo médico fundamenta el rol terapéutico que Evagrio asigna a la palabra del $A b b a$. Aquella figura parece constituir, en efecto, el modelo y la raíz del ministerio terapéutico que, en el pensamiento evagriano, puede ejercer el gnóstico.

\footnotetext{
1 Para una mayor noticia de la división evagriana de la vida cristiana puede consultarse: Evagrio Póntico (1971: 492-501; 1985: 21; 1987a: 343; 1995: 205-206). Ver Guillaumont (1971: 38-47; 2009: 205-207); Dysinger (2005: 27-29); Peretó Rivas (2014: 77-82); Konstantinovsky (2016: 130-132).
} 
De este modo, el aporte original que podrá realizar nuestro estudio también será doble. En primer lugar, se presentará un completo rastreo del tópico del Cristo médico en la obra evagriana. Este primer aspecto de nuestro aporte resulta de relevancia desde el momento en que se trata de un rastreo por el corpus evagriano que aún no ha sido realizado por la literatura especializada. Ciertamente existen estudios que tratan con distintas modulaciones el tema, como veremos en un momento. El segundo aspecto de nuestro aporte tiene que ver con la renovada comprensión, en que podría fructificar un estudio como el que aquí nos proponemos, del ejercicio logo-terapéutico que puede llevar adelante el gnóstico en el pensamiento de Evagrio Póntico. Como venimos diciendo, el gnóstico es, en el pensamiento del monje del Ponto, el hombre que, habiendo alcanzado una gnosis singular, puede, en virtud de ella, ejercer un auxilio terapéutico mediante su palabra (de allí aquella utilización que nos permitimos de la expresión logo-terapéutico, sin ulteriores menciones a la conocida escuela psicológica fundada por Viktor Frankl). Pues bien, creemos que enraizar, enmarcar, aquel auxilio terapéutico que puede brindar el gnóstico, en las implicancias que tiene la figura del Cristo médico en la obra evagriana, puede redundar en un renovado entendimiento acerca de la naturaleza y los alcances de la acción terapéutica que puede llevar adelante el gnóstico. De este modo, nuestro estudio podría significar una profundización original de un aspecto del pensamiento del Póntico no suficientemente indagado hasta aquí.

Por cierto, existen, dentro de los abundantes estudios acerca del pensamiento del Póntico que han ido apareciendo en las últimas décadas ${ }^{2}$, algunos que se han ocupado de tópicos semejantes al que aquí nos interesa. El ejemplo más notorio en este sentido lo constituyen los trabajos de Luke Dysinger, uno de los cuales resulta un antecedente directo de nuestro estudio. Nos referimos al trabajo "Healing Judgment: 'Medical Hermeneutics' in the Writing of Evagrius Ponticus", en el cual el estudioso norteamericano vincula el arte de la curación espiritual que puede llevar adelante el gnóstico, con el oficio terapéutico del Cristo médico (Dysinger, 2004: 100). En una obra más reciente, Dysinger (2016) se explaya en el asunto de la acción de auxilio que puede brindar el gnóstico a otros hombres, pero no se detiene a considerar el enlace de dicha acción con la figura del Cristo médico, acaso porque su objeto aquí es otro, a saber, considerar el lazo existente entre la exégesis y la guía espiritual, de acuerdo al pensamiento

2 Entre los más recientes se destacan los siguientes: Casiday (2013, 2015); Konstantinosky (2009, 2016); Kalvemaski (2014); Young (2016); Dysinger (2013, 2016); Cataldo (2007); Guillaumont (1996, 2009); Géhin (2007); Peretó Rivas (2015). 
del Póntico. Por otro lado, en la obra "Psalmody and Prayer in the Writings of Evagrius Ponticus" del mismo autor, encontramos un breve elenco de algunos de los lugares de la obra evagriana que se refieren a Cristo como "médico de las almas" o "médico" a secas (Dysinger, 2005: 115). Otro elenco semejante, junto a un breve comentario del asunto, lo hallamos en la obra de Julia Konstantinovsky (2009).

Asimismo, Evagrio es mencionado una vez en la exhaustiva presentación del asunto del Cristo médico en la Patrística que hace Jean-Claude Larchet (2007: 307). Gabriel Bunge, por su parte, en su estudio acerca de la paternidad espiritual en Evagrio, se refiere brevemente al Cristo médico en tanto modelo y ejemplo que debe seguir el padre espiritual en el auxilio medicinal que puede brindar (Bunge, 1994: 61). Lo señalado por Bunge constituye también, en este sentido, un antecedente importante de nuestro estudio.

Mencionemos por último la referencia hecha por Robin Darling Young al asunto del gnóstico en tanto médico. Tampoco esta estudiosa norteamericana se ocupa, pues no es su objeto, en vincular este ejercicio medicinal que puede llevar adelante el gnóstico con la figura del Cristo médico. Pero sí deja establecido claramente que el gnóstico puede, de acuerdo a Evagrio, llevar adelante dicho ejercicio (Young, 2016: 163).

La metodología de nuestro estudio será esencialmente hermenéutica ya que procuraremos entender a Evagrio desde Evagrio mismo. No obstante, no sólo haremos una lectura comprehensiva de sus obras, sino que también tendremos en cuenta a los autores de los que se nutre y a los autores con quienes dialoga. De allí la necesidad de presentar algunos trazos de los antecedentes históricos del tema del Cristo médico. El criterio de exposición será temático y comprensivo, que no cronológico puesto que no es posible desagregar cronológicamente la obra y el pensamiento del Póntico (no existen datos fehacientes acerca de los años en que escribió varias de sus obras) ni tiene sentido hacerlo desde el momento en que las ideas fuertes de su doctrina están dispersas en casi todas sus obras.

De este modo, nuestro estudio se organizará del siguiente modo: en primer lugar, mostraremos someramente cómo aparece en la obra evagriana el tópico de la acción medicinal que puede ejercer el gnóstico, pues es desde tal perspectiva que analizaremos el asunto del Cristo médico. Luego nos centraremos en la figura del Cristo médico, realizando, en primer lugar, un recorrido por algunos autores previos a Evagrio que trataron el tema, para luego centrarnos en el modo en que ésta aparece en la obra del Póntico, sus implicancias y la posibilidad de que, así concebida, sea esta figura - y asistiremos aquí al momento conclusivo de nuestro estudio- el fundamento de aquella función medicinal del gnóstico, en tanto modelo y condición de posibilidad de la misma. Es necesario tener en cuenta que, 
en lo que respecta al tratamiento evagriano propiamente dicho del tópico del Cristo médico, presentaremos la mayoría de los pasajes de la obra evagriana que se refieren a él, pero solo nos detendremos analíticamente en aquellos más relevantes para clarificar el asunto del rol terapéutico que puede ejercer el gnóstico.

\section{EL GNÓSTICO Y SU ACCIÓN MEDICINAL}

Sostenido en una ciencia que se ha hecho digno de recibir, el gnóstico puede, en el pensamiento del Póntico, ejercer una auténtica acción medicinal con su palabra. Él puede curar la ignorancia y sus males sucedáneos ${ }^{3}$ y por ello recibe de modo explícito, en diversos lugares de la obra evagriana, denominaciones vinculadas a esta virtualidad que posee su estado.

En el opúsculo "Sobre Maestros y Discípulos" es llamado por Evagrio Póntico (1997: 102-103) "médico de las pasiones", y su acción terapéutica es comparada con la del cirujano. En su "Tratado Práctico" nuestro autor señala que los ancianos — recordemos que así también es llamado quien ha alcanzado el conocimiento- nos curan de las mordeduras de las bestias salvajes que representan a los demonios (Evagrio Póntico 1971: 711). El gnóstico, indica en la obra homónima, cura a su prójimo aplicándole remedios (Evagrio Póntico 1989/2008: 151). Por su ciencia, señala en "Kephalaia Gnostica", hace pasar "a las almas racionales de la de malicia a la virtud y de la ignorancia a la ciencia" (Evagrio Póntico, 1985: 255). Por su ciencia, asimismo, puede curar la lepra de otros intelectos, subrayan los capítulos de los discípulos de Evagrio Póntico $(2007)^{4}$ evocando la exégesis que nuestro autor hace en otro lugar de las enfermedades que aparecen en el Levítico, entre ellas la lepra, como símbolos de enfermedades espirituales. La lepra del intelecto es la incredulidad. En otros sitios de aquellos capítulos, la tarea del médico es puesta como modelo de la acción del gnóstico: como el galénico, él puede enfadarse o mentir (Evagrio Póntico, 2007), pues él con su enseñanza también está curando. En un sentido semejante usa el sustantivo ia œúv en su carta 55, a fin de indicar el paradigma en que debe basarse el gnóstico al señalar un pecado al alma enferma: su palabra es como un bisturí afilado y la utilización de ella debe imitar el arte del médico. Debe estar oculta y aplicarse en el momento y la medida apropiados (Evagrio Póntico, 1987a). La imagen de un instrumento afilado

3 En otro lugar (Vazquez, En prensa) hemos demostrado que la enfermedad propia del alma (nous caído) para Evagrio es la ignorancia en cuanto ésta constituye el estado parà phýsin del centro de su ser, es decir, el logistikón o parte racional.

Acerca de la autoría evagriana derivativa de esta obra, consultar el estudio introductorio de Géhin (2007), y la guía online de Kalvemaski (2016). 
para simbolizar la palabra reaparece aquí. en los escolios a los Salmos, Evagrio Póntico (1960) la ha comparado a una espada al decir cómo ella separa al nous de la ignorancia ${ }^{5}$. La palabra es como un bisturí que el gnóstico médico aplica con el arte y la pericia que le da su conocimiento, su experiencia y su condición de contemplativo.

Gabriel Bunge ha unido o, por mejor decir, ha unificado las labores de médico y maestro que ejerce el gnóstico en el pensamiento evagriano. Se trata, en efecto, de dos labores inescindibles. El gnóstico cura, fundamentalmente, con el conocimiento, nos sana "con aquel óleo que es también símbolo del conocimiento", indica el comentador alemán citando las escolios a los salmos (Bunge, 1994: 61) ${ }^{6}$. Lo que indica Bunge, se comprende claramente cuando tenemos en cuenta que la enfermedad propia del alma es la ignorancia. De este modo el conocimiento que el maestro transmite es páguaxov (remedio, medicina) ${ }^{7}$ pues no se trata de un mero saber teórico sino de una gnosis que, como indica el mismo Bunge, es "el fruto de un camino de fe" y está fundada en las virtudes y, fundamentalmente, en el amor. El comentador alemán recoge un pasaje de las escolios evagrianas a los salmos que expresa brevemente esta idea: "A través del amor nosotros conocemos el amor y a través de lo que es justo conocemos la justicia. Por el igual, en efecto, se conoce el igual" (Escolios a los Salmos 17, 2, citado en: Bunge, 1994: 81) $)^{8}$.

Lo que transmite el gnóstico no es una mera instrucción sino la gnosis sanante que a él se la ha descubierto como fruto de su búsqueda amorosa e incansable.

Pero el primero y más importante de los mandamientos es el amor (Mc 12, 29) con el cual el intelecto ve el amor primordial, es decir Dios. Porque es mediante nuestro amor que vemos el amor de Dios por nosotros, como está escrito en el salmo "Él enseñará a los gentiles sus caminos" (Sal 24, 9): "Pero Moisés era más amable que todos los demás hombres" (Num. 12, 13), y el

5 "Esta espada separa el alma del vicio y el nous de la ignorancia" (Scholia on Psalms. 44, 4: en línea 2).

$6 \quad$ El texto que Bunge cita se encuentra, de acuerdo a su referencia, en dos lugares de "Escolias a los Salmos": 44, 8 y 88, 21. De estos textos de las escolias sólo el segundo se halla en la patrología griega (Evagrio Póntico, 1857: 1519). El texto restante de la escolia al versículo 8 del salmo 44 se encuentra en el manuscrito Vat Gr 754 cuya transcripción a cargo de la estudiosa de estas escolias, Marie-Josèphe Rondeau, le fue cedida a Bunge por la misma autora (Bunge, 1994: 13).

Más adelante veremos cómo nuestro autor llama, en sus "Escolias al Eclesiastés" (Evagrio Póntico, 1993: 60), phármakon a los lógoi de las cosas, a la ciencia que ellas otorgan.

$8 \quad$ Este pasaje de las escolias a los salmos tampoco se encuentra en la Patrología Griega de Migne, sino en el ya citado manuscrito V at. Gr. 754. 
Espíritu Santo dijo como es debido: "Él mostró a Moisés sus caminos" (cf. Sal. 102, 7). (Evagrio Póntico, 1987a, carta 56, 3; en línea1).

Se trata, precisamente, de la gnosis que cura la ignorancia porque ella es la interiorización de la verdad de la fe. No se trata de "ninguna especulación alambicada sobre la generación mítica de los eones y otros misterios esotéricos, sino el hecho, infinitamente simple, en el fondo - simple para quien ha tomado conciencia-, que Dios es amory que Él ha creado todo por amor, que mantiene todo en el ser y conduce todo a su cumplimiento por ese mismo amor" (Bunge, 1994: 84). De este modo, transmitiendo ese conocimiento el gnóstico es, a la vez, maestro y médico que cura cuando enseña.

Una opinión semejante a la de Bunge, tienen Guillaumont y Dysinger. El primero, comentando el último capítulo del "Tratado Práctico", subraya que el monje vive en el seno de una auténtica comunidad en la cual hay hermanos, sacerdotes encargados de celebrar los misterios, y ancianos "que sirven de instructores y enfermeros" (Guillaumont, 2009: 202). Dysinger insistirá, por su parte, en que el gnóstico ejerce "el gran arte de la curación espiritual" (Dysinger, 2004: 100), siendo a la vez maestro y médico que tiene su fuente en la Sagrada Escritura.

Ahora bien, en la concepción profundamente cristiana de Evagrio, esta función medicinal, brevemente esbozada aquí, que el gnóstico puede ejercer, se enraíza en, y alcanza su plena especificación a la luz de, la figura del Cristo médico. Dicha figura recibe en el pensamiento evagriano un importante tratamiento en el que nos interesa detenernos aquí. Diversos aspectos de dicho tratamiento esclarecen el modo en que Evagrio comprende aquel ejercicio medicinal que el gnóstico puede llevar a cabo. Nos centraremos ahora en el análisis de los lugares en los que Evagrio se refiere al Cristo médico no sin antes realizar un breve y somero recorrido por los abordajes que de esta figura cristológica realizan algunos pensadores cristianos que preceden a Evagrio y que pueden haber influido en su pensamiento.

\section{ANTECEDEnTES Históricos DE LA FIGURA DEL CRISTO MÉdiCO}

Para el tiempo de Evagrio esta imagen particularmente significativa de Jesucristo gozaba de una gran difusión pues ella expresaba una singular manera de comprender el proceso de salvación en tanto curación operada por el Médico divino.

Antes de aparecer en autores patrísticos directamente vinculados al pensamiento de Evagrio, como Clemente, Orígenes y Basilio, el título de médico aplicado a Cristo se encuentra tempranamente en San Ignacio de 
Antioquía, quien parece ser el primero que de modo explícito atribuye esta prerrogativa al Salvador. Posteriormente aparecerá en San Justino, en Teófilo de Antioquía, en San Irineo, en la historia apócrifa de los apóstoles conocida como "Actas de Juan" y que data del siglo II y en el escrito anónimo "A Diogneto" de finales del siglo II, entre otros. Ciertamente se trata de un título que tiene fundamento bíblico y que incluso puede inferirse de las palabras del mismo Cristo, no digamos de sus acciones que muchas veces son directamente curativas y medicinales. Dumeige (1972) recoge dos pasajes evangélicos en los que Cristo parece adjudicarse el título de médico. En primer lugar, la utilización del refrán "Médico cúrate a ti mismo", que el Mesías utiliza frente a sus incrédulos compatriotas que no ven en Él más que al hijo de José (Lc 4, 23). El contexto de estas palabras permite deducir que el mismo Cristo considera que el título de médico puede y debe ser aplicado a Él. En segundo lugar, aquella declaración de Jesús, aludida sin variaciones por los tres sinópticos, frente al reproche que le dirigen los fariseos de comer con publicanos y pecadores: "No son los sanos quienes tienen necesidad de médico, sino los enfermos" (Mt 9, 12; Mc 2, 17; Lc 5, 31). Por lo demás, Cristo despliega en su vida pública una auténtica y concreta acción medicinal y curativa que siempre simboliza y conduce a la salvación. A menudo, una purificación o una enseñanza espiritual sucede o antecede a una curación corporal. Se comprende así que, como afirma Dumeige, "más tarde los escritores hayan concentrado esta actividad curativa y salvadora que alcanza al hombre en sus enfermedades visibles y en su miseria invisible en la apelación dada a Jesús de "médico de los cuerpos y de las almas" (Dumeige, 1972: 116).

Pero hemos indicado que autores patrísticos directamente vinculados al pensamiento del Póntico como Clemente de Alejandría, Orígenes y Basilio, han aludido con mayor o menor extensión a este título atribuido a Jesucristo. Como ha indicado Juan Carlos Alby, "La escuela cristiana de Alejandría constituye un hito insoslayable en la historia de la doctrina del Lógos médico" (Alby, 2016: 118). En efecto, dicha doctrina recibe un particular tratamiento por parte de Clemente y Orígenes. Basilio, maestro de juventud de Evagrio (Guillaumont, 2009: 31-33), que ha tenido relación con esta escuela y que no se ha podido sustraer a su influjo, también a menudo otorga, por su parte, el título de médico a Cristo. Le llama "médico de las almas" (Basilio de Cesarea, 1857a: 433), "gran médico de almas" (Basilio de Cesarea, 1926: 306), "médico misericordioso" (Basilio de Cesarea 1857b: 865).

Como indica Ramelli (2015b) es por Basilio y por los dos Gregorios, el de Nacianzo y el de Niza, que Evagrio adquiere familiaridad con las ideas de Orígenes y, por medio de éste, con las de Clemente. Son Orígenes 
y su maestro Clemente, en efecto, quienes desarrollan con particular detenimiento el tema del Cristo médico.

Clemente en su discurso "¿Qué rico se salva?", indica, significativamente, que la acción médica de Cristo se revela en la parábola del buen samaritano.

¿Quién puede ser [el samaritano] sino el Salvador mismo? ¿Quién, más que Él, ha tenido más piedad de nosotros, que estábamos por así decir cazados por las potencias del mundo de las tinieblas, abrumados por una multitud de heridas, de temores, de deseos, de cóleras, de penas, de mentiras y de placeres? El único médico de esas heridas es Jesús, que extirpa radicalmente nuestras pasiones: a diferencia de la Ley, que se contenta con quitar los retoños y los frutos de las malas plantas, Él hace ir su propia hacha hasta las raíces del mal.

Se trata de una exégesis que, como veremos, reaparece en Evagrio. El Cristo Médico es en Clemente Logos therapeutikós que cura las pasiones mediante una acción educativa consistente en aconsejar y consolar.

Es como sanador y consejero a la vez que, sucediéndose a él mismo, exhorta al que primero ha convertido, y, especialmente, promete la curación de las pasiones que están en nosotros. Nosotros le daremos el solo nombre de Pedagogo que le conviene bien: el pedagogo, en efecto, se ocupa de la educación y no de la instrucción; su fin es hacer mejor al alma, no enseñarle (...) Las personas en buena salud no tienen necesidad de médico pues ellas está bien; los enfermos al contrario reclaman su arte. De la misma manera, nosotros que en esta vida estamos enfermos por nuestros deseos reprensibles, por nuestras intemperancias censurables, por todas las otras inflamaciones de nuestras pasiones, nosotros tenemos necesidad del Salvador. Él nos aplica dulces remedios, pero también remedios amargos (Clemente de Alejandría, 1960: 111 y 259).

Orígenes, por su parte, realiza un amplio tratamiento del tópico que no podría ser sintetizado con justicia aquí. El alejandrino trata de este asunto en diversos contextos: en sus comentarios y homilías, en su obra especulativa e incluso en su controversia con Celso donde contrapone el Cristo médico a Asclepio. Digamos simplemente que el alejandrino partiendo del evangelio dirá que Cristo ha venido a curar a los enfermos, Él es el Verbo eterno que ha descendido a dar la salud,

¿Qué hay de absurdo en que los médicos desciendan hacia los enfermos, y qué hay de absurdo en que el Médico supremo descienda él también hacia los enfermos? Los profetas eran numerosos médicos y mi Señor y Salvador es el Médico supremo [...] Estos es lo que inspira la filantropía médica; de la 
misma manera el Verbo ha inspirado al Salvador y a los profetas a venir no sólo aquí abajo, sino incluso a descender a los infiernos. (Orígenes, 1986: 191, 201).

Para Orígenes, Cristo es el médico supremo: sólo Él puede curar de modo completo porque Él no puede padecer enfermedad

[Dios] ha dado prueba de longanimidad enviándoles siempre alguien para curarlos, hasta que vino el Médico supremo, el Profeta que supera los profetas, el Médico que supera los médicos (Orígenes, 1977: 192). Yo no dudo que para su salud cada cual obedecería la advertencia del médico. He aquí que el médico de los cuerpos y de las almas ordena guardarse de la hierba de la embriaguez y de la orgía, y paralelamente de las preocupaciones del siglo como de ácidos mortales a evitar (Orígenes, 1981: 303).

Y en controversia con Celso reafirmará, en el marco de la metáfora médica y contraponiendo Cristo, "el médico de los cuerpos y de las almas", a Asclepios, el "demonio médico" (Orígenes, 1968: 59), la inmutabilidad y la santidad divinas.

[...] el médico que ve horrores y toca cosas repugnantes no evita absolutamente la posibilidad de contraer el mismo mal. Pero Aquel que cura las heridas de nuestras almas por el Logos de Dios presente en Él estaba él mismo fuera del alcance de todo mal. Incluso si, tomando un cuerpo mortal y un alma de hombre, el Logos, Dios inmortal, parece a Celso cambiarse y transformarse, que él aprenda que el Logos, que queda Logos por su esencia, no sufre ninguno de los sufrimientos del cuerpo o del alma (Orígenes, 1968: 221).

Resulta significativo observar cómo en Orígenes - y después en Evagrio- este Médico divino cura por sus palabras, que están en las Escrituras. El tópico de la palabra curativa aparece de modo explícito en el teólogo alejandrino. En el contexto de la figura del Cristo médico, es el mismo Mesías el que aplica de modos diversos estos medicamentos que son las palabras: "Es por la lectura de las Escrituras que se les administra todos los remedios de la enseñanza" (Orígenes, 1985: 75); "Ellos no experimentan los efectos curadores del evangelio" (Orígenes, 1943: 254); "Si tú ves un hombre herido por los pecados, y traspasado por las flechas del diablo, tú utilizarás las palabras de curación y emplearás la medicina de la palabra de Dios" (Orígenes, 1999: 175); "Esos que son sordos a las palabras salvadoras que les es ofrecida [por nuestro Salvador], son significados por los sordos" (citado en: Dumeige, 1972: 135).

El médico divino aplica en ocasiones remedios amargos y tratamientos penosos, pero siempre busca con ellos la salud: 
Los médicos introducen en los remedios sustancias amargas en vistas de perseguir la curación y la salud de los enfermos; el médico de nuestras almas actúa de la misma manera en vistas de nuestra salvación, Él ha querido que nosotros soportemos las amarguras de la vida de aquí abajo a través de variadas pruebas, porque sabía que esta amargura finalizaría por procurar a nuestra alma la dulzura de la salvación (Orígenes, 2001: 315).

El tema es ampliamente tratado por Orígenes y no sería posible sintetizar adecuadamente todo lo que el alejandrino indica al respecto. Baste con lo señalado para ver que cuando Evagrio se refiera al asunto, se está haciendo eco de una rica tradición que alcanza un particular despliegue en el marco de una corriente cara a su pensamiento como lo es la que se suscita en torno a los pensadores cristianos de Alejandría.

\section{El CRisto MÉdico EN LA OBRA EVAGRIANA}

En varias de sus obras el Póntico adjudica significativamente el título de médico a Cristo. Hagamos un breve recorrido a fin de visualizar los modos en que el tópico aparece en la obra del Póntico para intentar esclarecer, así como la acción medicinal que el gnóstico puede ejercer con su palabra en el pensamiento evagriano, encuentra en la figura del Cristo médico su raíz.

Comencemos por las escolias evagrianas al evangelio de Lucas, cuyo primer comentario (que es el que nos interesa aquî) se corresponde, con ligeras variantes, con seis kephalaia (199 a 204) de los "Capítulos de los discípulos de Evagrio”.

Una primera cosa llama la atención al acercarse a este texto y es que el título de médico es dado a Cristo, al igual que Clemente, en el marco de la exégesis de la parábola del buen samaritano.

Moisés condujo al hombre fuera del pecado en acto, pero su sucesor Jesús apartó el segundo, esto es, el pecado en pensamiento. Asimismo, el sacerdote no curó al hombre medio muerto, sino el Samaritano lo hizo, quien no dijo con la palabra del profeta, «No hay vestido, óleo, o vendaje para aplicar» (Is. 1, 6 LXX). Que El vino providencialmente es claro del hecho que Él tenía tales óleos y vendajes - porque Él trajo estas cosas consigo para muchos hombres heridos. Así los ángeles se mantuvieron fieles a la palabra de la vida, pero los demonios, a la de la muerte, y los hombres, a la palabra de los enfermos. El médico vino para estos últimos; con motivo de sus otros actos, Él es también llamado el «salvador». Ahora si una naturaleza racional se dice que está enferma, Él es llamado su «médico» (Evagrio Póntico, 2006a: 155). 
Jesús es el médico que ha bajado a curar a los enfermos que son los seres racionales. Los cura con aquel óleo (Ë̉aıov) que, como hemos visto, es símbolo del conocimiento. La palabra apropiada para los enfermos la da Él pues Él trae consigo aquel logos cuyo dulzor cura, como se ve en las escolias a los Proverbios:

[...] la cera corresponde a las realidades mismas, mientras que la miel que ellas contienen es el símbolo de su contemplación. Y la cera pasará, porque es dicho: 'El cielo y la tierra pasarán.' Pero la miel no pasará, porque no pasarán las palabras del Cristo nuestro Salvador, de las que Salomón habla en estos términos: 'Las buenas palabras son rayos de miel, su dulzor cura el alma’ (Evagrio Póntico, 1987b: 170).

Él cura con aquel óleo la enfermedad interna del alma, que no solo el acto exterior pecaminoso.

Pero Evagrio profundiza un poco más en este texto la analogía médica señalando a continuación los tres elementos que entran en juego en el acto de tratamiento médico: médico, medicina y paciente:

Hay tres cosas: el médico, la medicina y el paciente. Y si alguien toma la medicina pero no es curado, entonces él no ha sido curado o por las órdenes del doctor, o por la impotencia de las medicinas, o por su propia falta de disciplina. Pero el médico de las almas da órdenes apropiadamente, y sus mandamientos son apropiados a las pasiones - así, entonces, el hombre enfermo permanece sin curar debido a su propia falta de disciplina (Evagrio Póntico, 2006a: 155).

¿Por qué el "tratamiento" que lleva adelante el médico divino con el hombre enfermo puede no tener éxito? El médico divino que conoce en profundidad la enfermedad de su paciente — pues Él posee los principios que subyacen a su ser'- sabe por lo tanto qué medicamentos administrar, en qué forma, tiempo y medida. No es Él quien ha dado indicaciones equivocadas, ni son inútiles los medicamentos que ha prescripto pues solo ellos pueden orientar katà phýsin las pasiones. El motivo por el que el "tratamiento" puede no tener éxito se halla en la falta de disciplina del paciente.

Evagrio subraya, además, cuál es el medicamento dado por el Cristo médico que reúne las virtudes curativas de todos. A saber, aquella palabra que manda amar al Señor sobre todas las cosas y al prójimo como a sí

9 "Cristo, en la medida en que es el Cristo, posee conocimiento del Ser. En la medida en que es Creador, posee los principios subyacentes (lógoi) de las edades y los mundos. En la medida en que es incorpóreo, posee los principios subyacentes (lógol) de los seres incorpóreas" (Evagrio Póntico, 2001: 521). 
mismo. "El salvador ha prescripto una panacea" (Evagrio Póntico, 2006a:155), traduce Casiday. Un "medicamento condensado", traduce más literalmente Géhin (Evagrio Póntico, 2007: 265). La expresión griega es oúvтouov páquaxov. El amor, como hemos visto, es la puerta del conocimiento: Dios, que es "conocimiento sustancial" (Evagrio Póntico, 1985: 59), se revela a aquellos que lo buscan.

Otro lugar del corpus evagriano donde el título de médico es dado con frecuencia a Cristo, son las cartas que nuestro pensador ha dirigido a distintos destinatarios. La más extensa de estas epístolas es la dirigida a la anciana Melania, una de las responsables de la vocación monástica de Evagrio. En dicha carta, nuestro autor se refiere a un tema caro al pensamiento origenista: el de las denominaciones (ézivoıa ) de Cristo. Ya en las escolias al evangelio de Lucas ha planteado tímidamente el tema refiriendo aquella de médico, y la de pastor (Evagrio Póntico, 2006a: 155). Aquí, en la carta a Melania, deja establecido claramente que no siempre estas denominaciones son usadas en sentido metafórico. Claramente la de pastor sí. Pero no necesariamente la de médico pues, en el esquema evagriano, Cristo mediante su palabra puede efectivamente curar un alma que está realmente enferma.

Aquellos muchos nombres por los cuales Dios es nombrado se refieren a Él con respecto la diversidad de la creación racional, sea en su original sentido, sea en restrospectiva con respecto a la economía de salvación, sea en un sentido metafórico. Como por ejemplo, con respecto a los pecadores, «juez»; a los sin ley, «vengador»; a los enfermos, «médico»; con respecto a los muertos, «resucitadon»; a la enemistad y la muerte, «destructon», y así sucesivamente (Evagrio Póntico, 1987a: carta 24, línea1).

El tema de los epinoiai, reaparece en "Kephalaia Gnostica" (Evagrio Póntico,1985: 20), y es enmarcado en la cuestión de la caída de los seres racionales. Es con posterioridad a esta separación de los noes que Dios, y Cristo en tanto Dios, recibe las diversas denominaciones de "juez, gobernador, médico, pastor, doctor, y misericordioso y longánimo". La versión $\mathrm{S}_{1}$ del texto plantea una idea similar, aunque con más brevedad. Significativamente dicha versión menciona solo tres denominaciones, ninguna de las cuales parece ser meramente metafórica como sí lo son la de pastor o la de puerta, por ejemplo, que aparecen en $\mathrm{S}_{2}$. En esas tres denominaciones aparece la de médico: "Antes del movimiento, Dios era bueno, potente, sabio, creador, padre y omnipotente; después del movimiento, deviene juez, médico y providente" (Evagrio Póntico, 1985: 225).

Las cartas 51 y 52 , por otro lado, se refieren al médico de las almas en relación a la enfermedad de la vanagloria "que puede matar la capacidad 
de mi nous para el conocimiento" (Evagrio Póntico, 1987a: carta 52, 4, línea1). En efecto, la vanagloria puede impedir que el médico de las almas aplique "emoliente y aceite" (Evagrio Póntico, 1987a: carta 51, 2, línea1), es decir puede cerrar el nous al conocimiento y a la palabra bella que suaviza las heridas, y con lo cual el médico quiere sanar. Por ello es necesario, indica aquí Evagrio, no apartarse del médico de las almas y disponerse a recibir las vendas del desprecio y de los insultos con que él quiere curarnos. Quien se resiste al médico, termina actuando en contra de su voluntad, lo cual es decir que las pasiones lo dominan y pierde la libertad. Precisamente el estado opuesto a la apátheia que, como hemos visto, puede ser definida como libertad con respecto a las pasiones.

En la carta 42 ya ha indicado la confianza absoluta que hay que tener en el médico divino (Evagrio Póntico, 1987a: carta 42, 1, línea1). Él, como médico, sabe qué medicamentos impartir para "sacar virtudes de la maldad y traer conocimiento de la ignorancia" (Evagrio Póntico, 1987a: carta 42, 2 , línea1). En esta carta nuestro autor insta al destinatario, como lo propuso en las escolias al evangelio de San Lucas, a confiar en el "tratamiento" que el médico divino está realizando en su alma. Esta acción medicinal es la que lo llevará de la ignorancia al conocimiento.

Por último, en la carta 57 encontramos expresado claramente cómo para Evagrio la función medicinal de Cristo se inscribe en el designio providente de Dios. Asimismo, se indica de qué modo ejerce dicha función y cuál es el fin que la especifica.

Nuestros padres son sólo los padres de la carne, mientras que Dios es el «padre» del alma. Y así como la enfermedad del hijo aflige al padre, así el desorden del alma aflige a Dios. A la enfermedad del hijo el padre llama al médico; pero Dios envió del cielo el médico de nuestras almas, de manera que encantando a los seres humanos, de este modo los lleve así de la maldad a la virtud y de la ignorancia al conocimiento de Dios (Evagrio Póntico, 1987a: carta 57, 3, línea1).

Dios Padre, ante la enfermedad del alma, envía a su propio Hijo como médico. Éste cura encantando, hechizando, embelesando, fascinando, indica el texto explotando la riqueza semántica del verbo $\theta \dot{\varepsilon} \lambda \gamma \omega$. ¿Cómo ejerce esta acción el médico divino? Evidentemente con la palabra. En efecto, Evagrio, como hemos visto, ha indicado en sus "Escolias a los Proverbios" que las palabras de Cristo son lógoi kaloi (palabras buenas y bellas), semejantes a "rayos de miel, [cuyo] dulzor cura el alma" (Evagrio Póntico, 1987b: 170). Su dulzura y encanto cura el alma embelesándola.

Ahora bien, cabe preguntar ¿Qué hace que la acción de Cristo sea una acción medicinal? ¿Qué la especifica como tal? El texto nos lo indica: que 
ella busca, mediante la palabra encantadora, conducir de la ignorancia al conocimiento de Dios.

Otro lugar de la obra evagriana que adjudica más de una vez el título de médico a Cristo, es "Escolias a los salmos". En el comentario al versículo 3 del salmo 102 que reza: "Quien cura todas tus dolencias", escribe lacónicamente el Póntico: "Él cura enfermedades como médico de las almas" (Evagrio Póntico, 1960: línea2).

El sujeto del que se predica tal acción es, en el salmo, Yahvé. Deliberadamente Evagrio omite desde el comentario al versículo 1 de este salmo, la mención de Yahvé, para dar a entender que tales acciones pueden predicarse de modo particular respecto de la segunda persona de la Santísima Trinidad. Él es el médico que cura con su palabra. En efecto, algunas escolias más adelante dirá, también con laconismo: "La Palabra los cura de acuerdo al título de médico” (Evagrio Póntico, 1960: Sal 106, 20, línea2).

El Póntico ex profeso pone con mayúscula aquí - comentando el versículo 20 del salmo 106 que reza: "Él envía su palabra y los cura"- el término Palabra (Lógos). Cristo es aquí el Logos-médico, el médico-medicamento. Él es la Palabra misma que cura pues, como hemos visto en los Skemmata evagrianos, los lógoi (que según las "Escolias al Eclesiastés" son phármaka [Evagrio Póntico, 1993: 60]) están y son en Él. El lógos de sí que el nous ha perdido con su caída, está en Él y por eso Casiday se permitirá decir que aquel rostro desaparecido de la imagen que el alma pecadora tiene de sí, según capítulo 25 del "Tratado sobre los Pensamientos", es el propio rostro de Cristo (Casiday, 2013: 185; 2015: 45-47), a cuya imagen el alma ha sido hecha. El alma enferma de ignorancia debe descubrir su propio lógos en el rostro de Cristo.

En un lugar más de las "Escolias a los Salmos" Evagrio llama médico a Cristo, a saber, en el comentario al versículo 6 del salmo 144. El comentario sugiere, a la luz de otros textos, lo siguiente: el médico de las almas cura con el conocimiento, con la enseñanza, con su palabra. Dice en el primero: "Como un médico de las almas Cristo les da su alimento a su debido tiempo" (Evagrio Póntico, 1960: Sal 144, 6, línea2).

Cuál sea ese alimento nos lo ha dicho en otros lugares:

De la misma manera que no son las materias las que alimentan los cuerpos, sino su potencia, así también no son los objetos los que hacen crecer el alma,

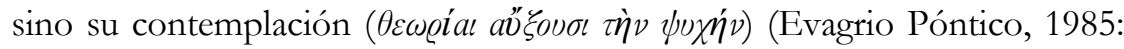
73).

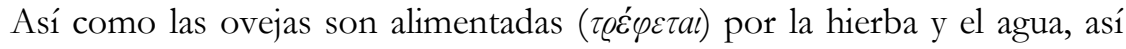
también la persona humana es vivificada en la práctica ascética (praktikề) por la práctica y el conocimiento (Evagrio Póntico, 1960: Salmo 22, 1, línea2). 
Mediante la praktiké el Señor rescata a uno de la muerte; luego a través del

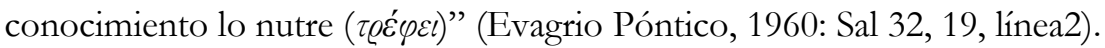

Así como durante el sueño al absorber el alimento la digestión nutre el

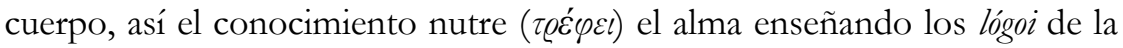
praktiké (Evagrio Póntico, 1960: Sal: 126, 1, línea2).

El alimento que el médico da a las almas enfermas es precisamente aquel cuya carencia las tiene enfermas: el conocimiento. Pero se los da a su debido tiempo y dosificado, como un buen médico que equilibra la dieta

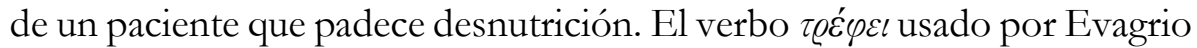
posee una extensión semántica que Evagrio explota en estos textos. El mismo designa la acción de nutrir y alimentar, pero también la de formar, educar, instruir, incluso es usada en el contexto médico antiguo para designar el acto maternal concreto de amamantar a un niño (Grimaudo, 2012). El alimento del alma es la educación, la instrucción, la enseñanza del médico divino, que con su palabra, con los lógoi de las cosas, "hace crecer al alma", la fortalece, la lleva a la edad adulta pues todo esto significa el verbo $a \mathfrak{\jmath} \xi a ́ v \omega\left(a \jmath \xi_{0} v \sigma \iota\right.$ en la cita) que Evagrio usa en el primer texto referido para designar el efecto benéfico que tiene la contemplación de los lógoi sobre el alma. Como la leche materna de la que el niño tiene una necesidad imperiosa para crecer sano, así necesita el alma del conocimiento que el médico divino le da cual una madre que amamanta a su hijo atendiendo con amor a su necesidad más primaria. En las escolias a los Proverbios, Cristo es llamado también "madre" y lo es en consonancia con esta idea. Él es "la madre de esos que tienen necesidad de leche" (Evagrio Póntico, 1987b: 306).

En el tratado "Sobre los Pensamientos" también se referirá Evagrio a Cristo como el médico de las almas, y lo hará en dos ocasiones. En la primera, el título de médico es aplicado al Salvador en el marco de la exégesis del capítulo 6 del evangelio de San Mateo en el cual Cristo manda orar, hacer limosna y ayunar sin buscar que los hombres lo vean. Jesús "instruye en estos términos al piloto que es el intelecto" (Evagrio Póntico, 1998: 160). Y las palabras que aquí dice deben ser interpretadas, para Evagrio, como prescripciones de un médico:

Pero es al médico de las almas al que es necesario observar aquí: cómo por la limosna trata $(\theta \varepsilon \varrho a \pi \varepsilon u ́ \omega \varepsilon \iota)$ la parte irascible, por la oración purifica el intelecto y aún por el ayuno extenúa la parte concupiscible; de suerte que se forme 'el hombre nuevo renovado a imagen de su Creador' (Evagrio Póntico, 1998: 162). 
Para curarnos el Médico divino se dirige al intelecto: le enseña, lo educa, le da instrucción ( $\pi a \iota \delta \varepsilon \dot{v} \omega \nu)$, le prescribe claramente qué hacer para curar cada parte de su alma. Y citando la carta paulina a los Colosenses, Evagrio especifica claramente cuál es el objetivo final de la acción terapeútica del Cristo médico: reconstituir Su imagen en el intelecto. Con ello volvemos a aquello que indicábamos hace un momento respecto a la necesidad de que el alma enferma descubra su propio lógos en el rostro de Cristo.

La segunda mención que en este tratado Evagrio hace del médico divino es en el capítulo 10. Allí indica que el remedio que aplica al alma que no se puede desembarazar de la amistad, del afecto, del gusto por los es-

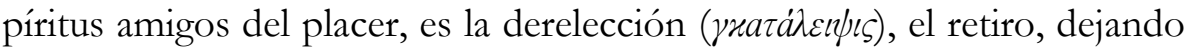
que los espíritus malignos asedien al alma con alucinaciones y pesadillas. Con ello logra que el alma vuelva a odiar a los demonios.

Por último, en los "Capítulos de los Discípulos de Evagrio", también se habla del médico divino. Esta vez en el marco del tratamiento del orgullo. Intentando guardar al lector contra las ramificaciones del orgullo, el autor subraya que este vicio también se expresa cuando, habiendo realizado buenas acciones, se cae en la tentación de denigrar a los hermanos que no las hacen. Con ello se denigra al mismo Cristo que, con criterio de médico experto, libera de las pasiones a algunos más rápidamente que a otros atendiendo a su circunstancia particular, y al desarrollo singular de la enfermedad en cada uno (Evagrio Póntico, 2007: 152).

\section{El CRISTO MÉDICO Y EL EJERCICIO MEDICINAL DEL GNÓSTICO}

Pues bien, hemos indicado que es en esta figura del Cristo médico que se enraíza la función medicinal que Evagrio da al gnóstico ¿En qué sentido es así?

Cristo, como venimos viendo, posee los principios subyacentes de todas las cosas, esos lógoi que curan. Éstos son esos phármaka (Evagrio Póntico, 1993: 60) y esos lógoi kaloí (Evagrio Póntico, 1987b: 170) cuyo dulzor cura encantando (Evagrio Póntico, 1987a: carta 57, 3, línea1), según hemos visto. Y el gnóstico es -en virtud del don de la ciencia que se le ha dado al cabo de la labor práctica, según hemos visto- quien es capaz de descubrir esos phármaka y comunicarlos a los demás.

La palabra del Gnóstico es, de este modo, un puente entre el alma enferma de ignorancia y la palabra sanadora del médico divino acerca de sí misma y de las cosas. El gnóstico es quien es capaz de descubrir y proferir la palabra divina que nombra al alma y en la cual ésta debe reconocerse para alcanzar la salud. Y este es el sentido primario en que la función medicinal que el gnóstico puede ejercer con su palabra se fundamenta en el ministerio médico que Cristo ejerce al crear las cosas. Cristo crea para 
curar al alma, para que el alma descubra en las cosas el amor de Dios por ella que resulta el fundamento de su propio ser. ${ }^{10}$ El gnóstico que se ha hecho digno de descubrir esa belleza escondida de todas las cosas y el modo en que ellas se refieren al alma, puede en virtud de ello secundar la acción medicinal de Cristo llevando a las almas enfermas "de la ignorancia a la ciencia", como dice Evagrio al cerrar "Kephalaia Gnóstica": "Quienquiera haya obtenido la ciencia espiritual ayudará a los ángeles y llevará las almas racionales de la malicia a la virtud y de la ignorancia a la ciencia" (Evagrio Póntico, 1985: 255).

Un texto de las escolias al Eclesiastés resulta significativo en este sentido:

Si 'el Cristo es la cabeza de todo hombre' y si el sabio también es un hombre, el Cristo es la cabeza del sabio. Pero ya que el Cristo es nuestra sabiduría - 'porque ha sido engendrado para nosotros sabiduría por Dios'-, la cabeza del sabio es pues la sabiduría, en la cual el sabio tiene los ojos del pensamiento cuando contempla en ella las razones de los seres creados (Evagrio Póntico, 1993: 76).

Retomando una idea de Orígenes que comentando el mismo pasaje del Eclesiastés ("Los ojos del sabio están en su cabeza" [Ecl. 2, 14]) afirma que la mentada cabeza es, de acuerdo al texto paulino también citado por Evagrio, Cristo (Orígenes, 1960: 97), nuestro autor sugerirá que el gnóstico -que es el sabio del texto escriturario- mira y ve con los ojos de Cristo. El gnóstico tiene sobre los seres racionales que son objeto de su contemplación, los ojos sanadores de Cristo. Ve en los seres racionales lo que el mismo Cristo ve en ellos y puede así devolverles la palabra sanadora que le descubre su propio ser pues es Cristo quien lo ha creado y quien tiene, en el esquema evagriano, como venimos insistiendo, los "principios subyacentes de los seres inteligibles” (Evagrio Póntico, 2001: 521).

Por otro lado, en las escolias 163 y 164 al libro de los Proverbios, Evagrio funda la posibilidad de que los hombres santos y justos lleven a otros hombres de la ignorancia a la ciencia de Dios - es decir, de la salud a la enfermedad-, en el hecho de que ellos son engendrados por la sabiduría.

10 Respecto al rol que Evagrio asigna a Cristo en la creación del mundo y a cómo dicha creación es el fruto de un designio sanante y salvador de la Providencia que mediante ella busca "hacer subir al nous a su rango primero" (Evagrio Póntico, 1985: 115). Ver: Evagrio Póntico (1985: 61, 101, 115); Dysinger (2005: 33); Guillaumont (2009: 347); Konstantinovsky (2009: 55-60). Para visualizar, por otro lado, el modo en que el rol terapeútico del lógos es inscripto, para el cristianismo tardoantiguo del tiempo de Evagrio, en el designio salvador de la Providencia, se puede consultar: Harrison (2013: 10-11). 
Si los hijos del Cristo son «hermanos» los unos de los otros y si los ángeles y los hombres justos son los hijos del Cristo, los ángeles y los hombres santos son pues «hermanos» los unos de los otros, porque ellos son engendrados por el espíritu de filiación adoptiva. [...] «Ellos son en efecto engendrados» por la sabiduría para llevar los hombres de la malicia a la virtud y de la ignorancia a la ciencia de Dios (Evagrio Póntico, 1987b: 260).

Es decir, es Cristo mismo el que los engendra para que sean capaces de ejercer aquella acción medicinal. Por ello estos hombres -los gnósticos- son "hijos del Cristo" y "hermanos los unos de los otros". La sabiduría que se identifica con Cristo es aquella "plena de variedades", con la cual el Salvador ha creado los mundos (Evagrio Póntico, 1985: 61), "la multiplicidad de la creación postlapsaria", como escribe Ramelli (2015a: 86). Esta sabiduría es la que engendra al gnóstico, la que lo trae al ser como tal pues es la que lo ha curado, la que le ha devuelto un registro verdadero y pleno de sí (el que el Cristo tiene de él), la que lo ha hecho pasar de la ignorancia a la ciencia y la que le permite así colaborar en la acción medicinal de Cristo con otros hombres.

Esta ciencia espiritual o sabiduría a partir de la cual el gnóstico, auxiliando a los ángeles, ejerce una enseñanza curativa" "es la ciencia concerniente a las enfermedades del alma, que hace subir a la salud a los que están heridos" (Evagrio Póntico, 1985: 117). Es decir, el gnóstico, en virtud de esta ciencia medicinal del Cristo de la que ha sido juzgado digno, reconoce en la ignorancia la enfermedad profunda del alma y es a partir de este reconocimiento y de esta $\delta \iota \dot{\gamma} \nu v \omega \sigma \varsigma^{12}$, que puede ejercer una acción curativa. Por ello Evagrio insiste en que, al ser "engendrado por la sabiduría", al obtener la ciencia espiritual que incluye los lógoi de la enfermedad, el gnóstico puede hacer pasar de la ignorancia a la ciencia a las almas enfermas. Por ello a los ancianos o gnósticos "es necesario honrarlos como los ángeles: son ellos, en efecto, quienes nos ungen para los combates y nos curan las mordeduras de las bestias salvajes" (Evagrio Póntico, 1971: 711).

En la primera parte de su carta a Melania o "Gran Carta", Evagrio utiliza otra bella y esclarecedora metáfora para referirse a la ciencia natural y al rol del gnóstico en relación con ella. Las creaturas, indica, son las cartas que Dios escribe a los hombres con su sabiduría que es el Hijo, y son los

$11 \Delta \iota \delta a ́ \sigma x \varepsilon v$ es el verbo que utiliza Evagrio Póntico (1987b: 388 y 444) en las escolias a los Proverbios para designar la acción que realizan los ángeles -y los gnósticos auxiliándolos- para con los pecadores enfermos.

12 Este término es usado por nuestro autor en el opúsculo "Sobre maestros y discípulos" para designar aquel ejercicio de discernimiento sobre el alma del prójimo que

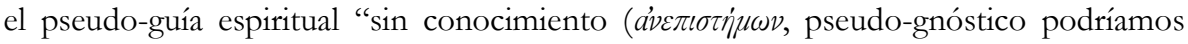
decir)" se ve incapacitado de hacer (Evagrio Póntico, 1997: 102). 
gnósticos quienes son capaces de leer las palabras que Dios ha escrito en ellas. El que no sabe leer puede conocer el designio de Dios sobre las cosas y sobre él mismo haciéndose leer esas cartas: sus orejas deben suplir a sus ojos (Evagrio Póntico, 2006b: 64-65). Como indica Guillaumont comentando este pasaje, el práctico debe ponerse a la escucha del gnóstico (2009: 373). Éste posee la ciencia, el lógos, la "sabiduría plena de variedades del Cristo", capaz de curarlo.

De este modo, y haciendo nuestras las palabras de Luke Dysinger, "el gnostikos, el cristiano contemplativo, es llamado a practicar el gran arte de la curación espiritual y así compartir el oficio terapeútico de Cristo" (Dysinger, 2004: 100).

\section{CONCLUSIÓN}

Como vemos la obra evagriana abunda en el tratamiento de este tópico eminentemente patrístico del Cristo médico. No nos ha sido posible examinar con detalle todas las implicancias de dicho tratamiento. Si bien hemos consignado los numerosos pasajes en los que el monje del Ponto trata el asunto (presentado así, por otra parte, un rastreo útil para futuras investigaciones) nuestro recorte metodológico nos ha llevado a considerar con mayor detenimiento solo aquellos pasajes que pueden resultar relevantes para clarificar el asunto de la acción terapéutica que pude llevar adelante el gnóstico. Este, en efecto, ha constituido el objetivo central de nuestro estudio.

Hemos podido verificar que, tal como lo conjeturamos al iniciar nuestro recorrido, el asunto de la acción terapéutica del gnóstico se ve clarificado en su naturaleza, en su alcance y en su finalidad cuando se consideran las implicancias conceptuales que posee la idea del Cristo médico en Evagrio. En efecto, el gnóstico, en virtud del conocimiento que ha recibido, puede y debe participar del oficio terapéutico que el Cristo ejerce al crear. Éste posee los principios subyacentes de las cosas, sus lógoi, que son llamados phármaka por Evagrio. Estos medicamentos le son dados al gnóstico al cabo de su progreso espiritual, y él puede administrarlos transformándose así en una especie de puente entre el alma enferma y el médico divino que posee la ciencia capaz de curarla.

De este modo, nuestro estudio ha permitido realizar un doble aporte a los estudios evagrianos. Por un lado, ofrece un panorama del tratamiento del tópico del Cristo médico en la obra del filósofo del Ponto. Por otro, permite - a la luz de algunos aspectos de dicho tratamiento- profundizar en la naturaleza y en las proyecciones terapéuticas que posee una figura central del pensamiento de Evagrio como es la del gnóstico. 


\section{REFERENCIAS}

-Alby, J. C. (2016). El logos médico en la escuela cristiana de Alejandría. El laberinto de Arena, 3(6), 111-118.

-Basilio de Cesarea (1857a). Homiliae in Psalmos. En J.P. Migne (Ed.), Patrologia Graeca (Vol.29). San Diego: University of California.

-Basilio de Cesarea (1857b). Moralia. En J.P. Migne (Ed.), Patrologia Graeca (Vol.31). San Diego: University of California.

-Basilio de Cesarea (1926). The Letters (R.J. Deferrari, Trad.). London: The Loeb Classical Library.

-Bunge, G. (1994). Paternité Spirituelle. La gnose chrétienne chez Évagre le Pontique. Bégrolles en Mauges: Abbaye de Bellefontaine.

-Casiday, A. (2013). Reconstructing the theology of Evagrius Ponticus: beyond heresy. Cambridge: Cambridge University Press.

-Casiday, A. (2015). Connaissance de soi et examen de conscience - Évagre le Pontique (IVe siècle), Communio (40), 39-48.

-Cataldo, G. (2007). Vita come tensione nell'antropologia di Evagrio Pontico. Bari: Ecumenica Editrice.

-Clemente de Alejandría (1960). Le Pédagogue. Livre. En Sources Chrétiennes 70 (M. Marrou y Marguerite Harl, Trad.). Paris: Cerf.

-Dumeige, G. (1972). Le Christ médecin dans le littérature chrétienne des premiers siècles. Rivista di archeologia Cristiana, 48 (1972), 115-141.

-Dysinger, L. (2004). Healing Judgment: 'Medical Hermeneutics' in the Writing of Evagrius Ponticus. En M. Bielawski \& D. Hombergen (Eds.), Il monachesimo tra eredità e aperture: atti del simposio "Testi e temi nella tradiz̧ione del monachesimo cristiano" (págs. 75-104). Roma: Pontificio ateneo S. Anselmo.

-Dysinger, L. (2005). Psalmody and Prayer in the Writings of Evagrius Ponticus. New York: Oxford University Press.

-Dysinger, L. (2013). An Exegetical Way of Seeing: Contemplation and Spiritual Guidance in Evagrius Ponticus, Studia Patristica, 57, 31-50.

-Dysinger, L. (2016). Evagrius Ponticus, Exegete of the Soul. En J. Kalvesmaki \& R. D. Young (Eds.), Evagrius and His Legacy (pp. 73-95). South Bend: University of Notre Dame Press.

-Evagrio Póntico (1857). Selecta in Psalmos. En J.P. Migne (Ed.), Patrologia Graeca (Vol.12). San Diego: University of California.

-Evagrio Póntico (1960). Scholia on Psalms. (L. Dysinger, Trad). Recuperado de Saint John's Seminary, http://www.ldysinger.com/Evagrius/08_Psalms/00a_start.htm.

-Evagrio Póntico (1971). Traité Pratique ou le moine. En Sources Cbrétiennes, 171 (A. Guillaumont \& C. Guillaumont, Trads). Paris: Cerf.

-Evagrio Póntico (1985). Les six centuries des 'Kephalaia gnostica' d’Évagre le Pontique. En Patrologia Orientalis (T. XXVIII, A. Guillaumont). Paris: Brepols.

-Evagrio Póntico (1987a). Letters. (L. Dysinger, Trad). Recuperado de Saint John's Seminary http://www.ldysinger.com/Evagrius/11_Letters/00a_start.htm. 
-Evagrio Póntico (1987b). Scholies aux Proverbes. En Sources Chrétiennes 340 (P. Géhin, Trad.). Paris: Cerf.

-Evagrio Póntico (1989/2008). Le gnostique ou a calui qui est devenu digne de la science. En Sources Chrétiennes 356, (A. Guillaumont y C. Guillaumont, Trad.). Paris: Cerf.

-Evagrio Póntico (1993). Scholies à l'Ecclésiaste. En Sources Chrétiennes 397 (P. Géhin, Trad.) Paris: Cerf.

-Evagrio Póntico (1995). A los monjes. En J.I. González \& J.P. Rubio, Obras espirituales (pp. 177-211). Madrid: Ciudad Nueva.

-Evagrio Póntico (1997). On teachers and Disciples. Hallel, 22, 96-103.

-Evagrio Póntico (1998). Sur les pensées., En, Sources Chrétiennes 438 (P. Géhin, C. Guillaumont y A. Guillaumont) Paris: Cerf.

-Evagrio Póntico (2001). The sapphire light of the mind: the Skemmata of Evagrius Ponticus, Theological Studies, (62), 498-529.

-Evagrio Póntico (2006a). Notes on Luke. En: Evagrius Ponticus (A. Casiday, Trad., pp. 153-161). London, Routledge.

-Evagrio Póntico (2006b). The Great Letter. En, Evagrius Ponticus (A. Casiday, Trad. pp. 63-77). London: Routledge.

-Evagrio Póntico (2007). Chapitres des disciples d’Évagre. En Sources Chrétiennes 514 (P. Géhin, Trad.). Paris: Cerf.

-Géhin, P. (2007). Introduction Évagre le Pontique. Chapitres des disciples d'Évagre. En Sources Chrétiennes, 514. Paris: Cerf.

-Grimaudo, S. (2012). Galeno, La salute (De sanitate tuenda-Libro I). Palermo, Duepunti edizioni.

-Guillaumont, A. (1971). Introduction. En Sources Chrétiennes, 171 (A. Guillaumont \& C. Guillaumont, Trads.). Paris: Cerf.

-Guillaumont, A. (1996). Études Sur La Spiritualité De L'orient Chrétien. Bégrollesen-Mauges: Abbaye de Bellefontaine.

-Guillaumont, A. (2009). Un philosophe au désert. Évagre le Pontique. Paris: Vrin.

-Harrison, C. (2013). The Art of Listening in the Early Church. Oxford: Oxford University Press.

-Kalvemaski, J. (2014). The Soul's Cure in Letters: The Death of Gregory of Nazianzus and the Consolation of Evagrius of Pontus. The American Benedictine Review, 65(2), 135-144.

-Konstantinovsky, J. (2009). Evagrius Ponticus. The Making of a Gnostic. Farnham: Ashgate.

-Konstantinovsky, J. (2016). Evagrius Ponticus and Maximus the Confessor The building of the Self in Praxis and Contemplation. En J. Kalvesmaki \& R. D. Young (Eds.), Evagrius and His Legacy (pp. 128-153). South Bend: University of Notre Dame Press.

-Larchet, J. C. (2007). Thérapeutique des maladies spirituelles. Paris: Cerf.

-Orígenes (1943). Homélies sur la Genèse. En Sources Chrétiennes, 7 (L. Doutreleau, Trad.). Paris, Cerf.

-Orígenes (1960). Entretien avec Héraclide. En Sources Chrétiennes, 67 (J. Scherer, Trad.). Paris: Cerf. 
-Orígenes (1968). Contre Celse. Livres III et IV. Introducción, traducción y notas de. En Sources Chrétiennes, 136 (M. Borret). Paris: Cerf.

-Orígenes (1977). Homélies sur Jérémie (XII-XX et Homélies latines), tome II. En Sources Chrétiennes, 238 (M. Nautin y M. Husson, Trad.). Paris: Cerf.

-Orígenes (1981). Homélies sur le Lévitique (I-VII), tome I. Sources Chrétiennes, 286 (M. Borret, Trad.). Paris: Cerf.

-Orígenes (1985). Homélies sur l'Exode. En Sources Chrétiennes, 321 (M. Borret). Paris: Cerf.

-Orígenes (1986). Homélies sur Samuel. Sources Chrétiennes, 328 (M-T. Nautin y M.P. Nautin). Paris: Cerf.

-Orígenes (1999). Homélies sur les Nombres, II (Homélies XI-XIX). En Sources Chrétiennes, 442 (M. Borret y L. Doutreleau, Trad.). Paris: Cerf.

-Orígenes (2001). Homélies sur les Nombres, III (Homélies XX-XXVIII). En Sources Chrétiennes, 461 (M. Borret y L. Doutreleau, Trad.). Paris: Cerf.

-Peretó Rivas, R. (2014). Conocimiento e ignorancia en Evagrio Póntico. Cauriensia, (9), 75-93.

-Peretó Rivas, R. (2015). Las doctrinas secretas en la obra de Evagrio Póntico. Mediaevalia, (32), 15-28.

-Ramelli, I. (2015a). Evagrius's Kephalaia Gnostica: A New Translation of the Unreformed Text from the Syriac. Atlanta: SBL Press.

-Ramelli, I. (2015b). Introductory Essay: Recovering the True Thought of the Origenian Evagrius: A Needed Reassessment of the Influence of Origen and Gregory of Nyssa on Evagrius. En Evagrio Pontico, Evagrius's Kephalaia Gnostica: A New Translation of the Unreformed Text from the Syriac (pp. xi-lxxxviii). Atlanta: SBL Press.

-Young, R.D. (2016). The Role of Letters in the Works of Evagrius. En J. Kalvesmaki \& R. D. Young (Eds.), Evagrius and His Legacy (pp. 154-174). South Bend: University of Notre Dame Press.

Sumario: Introducción; 1. El gnóstico y su acción medicinal; 2. Antecedentes históricos de la figura del Cristo Médico; 3. El Cristo médico en la obra evagriana; 4. El Cristo médico y el ejercicio medicinal del gnóstico; Conclusión; Referencias. 